\title{
Beneficial Bacillus Strains Improve Plant Resistance to Phytopathogens: A Review
}

\author{
Sergiu Fendrihan*, Florica Constantinescu, Oana-Alina Sicuia, Sorina Dinu
}

Research and Development Institute for Plant Protection, 8 Ion Ionescu de la Brad Blvd.,013813, Bucharest, Romania

\begin{abstract}
Fungal diseases are producing important damages to cultivated plants. The conventional way to reduce the pathogenic attack in plants is the use of chemical fungicides. However, high amounts of syntactical pesticides can contaminate food and feed yields with chemical residues. An environmental friendly method to exclude pesticide contamination is the use of biological control products, such as microbial based products. Beneficial strains of Bacillus are highly appreciated for biological control, as they are spore forming bacteria, easy to formulate and preserve. Bacillus strains can produce a wide range of metabolites that stimulate plant growth and, at the same time, reduce plant pathogens attack, either by suppressing fungal growth or inducing plants' resistance to pathogens. The paper reviews this problem critically, highlighting some common features of the Bacillus beneficial strains, using an important amount of new literature material.
\end{abstract}

Keywords- Bacillus strains, biological control, resistance to phytopathogens, endophytes, rhizosphere.

\section{INTRODUCTION}

The development of Plant Growth Promoting Bacteria (PGPB) concept, in the $\mathrm{XX}^{\text {th }}$ century, promoted bio-based fertilizers on the market in many countries. Beneficial Bacillus strains are included in the category of PGPB, and due to their spore forming ability, commercial interest is still at high level as they are easy to formulate and preserve. Several species from Bacillus genus were found to have beneficial strains of industrial and agricultural interest. Such species include B. thuringiensis, which is the most used microorganism, highly appreciated for insect biological control; and $B$. subtilis, $B$. amyloliquefaciens, B. licheniformis, B. pumilus used for antibiotics and/or enzymes production, but also for plant protection and/or growth promotion. Along with Bacillus genus there are also some other related genera, such as Brevibacillus and Paenibacillus for example, that are also mentioned as beneficial [1]. In fact, such bacteria, express their influence on plants by producing a wide range of beneficial metabolites, such as phytohormones, volatile compounds, siderophores; enzymes, such as ACC- deaminase (1-aminocyclopropane-1-carboxylatedeaminase), and other carboxylases, phosphate solublilizing enzymes; nitrogen fixation, and/or induce resistance in plants against phytopathogens, and so on [2, $3]$, either as endophytes or from rizosphere, PGPB improve plant response to adverse condition and increase their productivity.

\section{ISOLATION OF PLANT BENEFICIAL BACTERIA}

There is a permanent debate regarding plant protection products, highlighting the benefits and drawbacks of the chemically synthesized and biological means. Because of the high toxicity of the chemical pesticides and low efficiency of the microbial based products, scientists made efforts to improve the biological control and microbial formulations.

When isolating plant beneficial bacteria, either as endophytes or from the rhizosphere, it is important to apply multiple selection tests and evaluate the spectrum of plant growth promoting activities and biocontrol potential. A complex analysis of the microbiota present in the rhizosphere of Phyllantus amarus revealed the presence of aerobic and endospore forming bacteria of Bacillus, Lysinibacillus, Paenibacillus, Terribacillus and Jeotgalibaccillus. Of these isolates $92 \%$ were shown to produce indole acetic acid, $87 \%$ were able to solubilize phosphate, $44 \%$ produced siderophore, $42 \%$ revealed chitinase activity, 21\% ACC-deaminase, and $46 \%$ revealed antagonistic activity against common plant pathogens [4]. Biocontrol and biofertilizing ability was also shown in Bacillus spp. strains isolated from agricultural lands of Romania. The isolated strains showed cellulase, amylase, and lactonase activity, motility, biofilm formation ability, tomato seedlings growth promotion, improved wheat germination and antifungal activity against Alternaria sp., Botrytis cinerea, Fusarium oxysporum and F. graminearum, Sclerotium bataticola [5]. The complex relations between the environment - plants - and microbes are shown in Figure 1.

Mutual and/or symbiotic relations between beneficial microorganisms grown as endophytes or in the 
rhizosphere and aerial organs of their host plants are revealed in the studies of plant growth- and plant healthpromoting bacteria [6].

Endophyte bacteria, such as Bacillus megaterium found in Panax gingseng [7], strains of Bacillus spp. and Paenibacillus spp. isolates from leguminous and non- leguminous plants [8], Bacillus spp. isolates from strawberry plants [9] showed plant growth promoting ability by producing auxins, citokinins, ACC-deaminase, siderophores and other compounds that are improving the growth and defense of cultivated plants, increasing plant productivity.

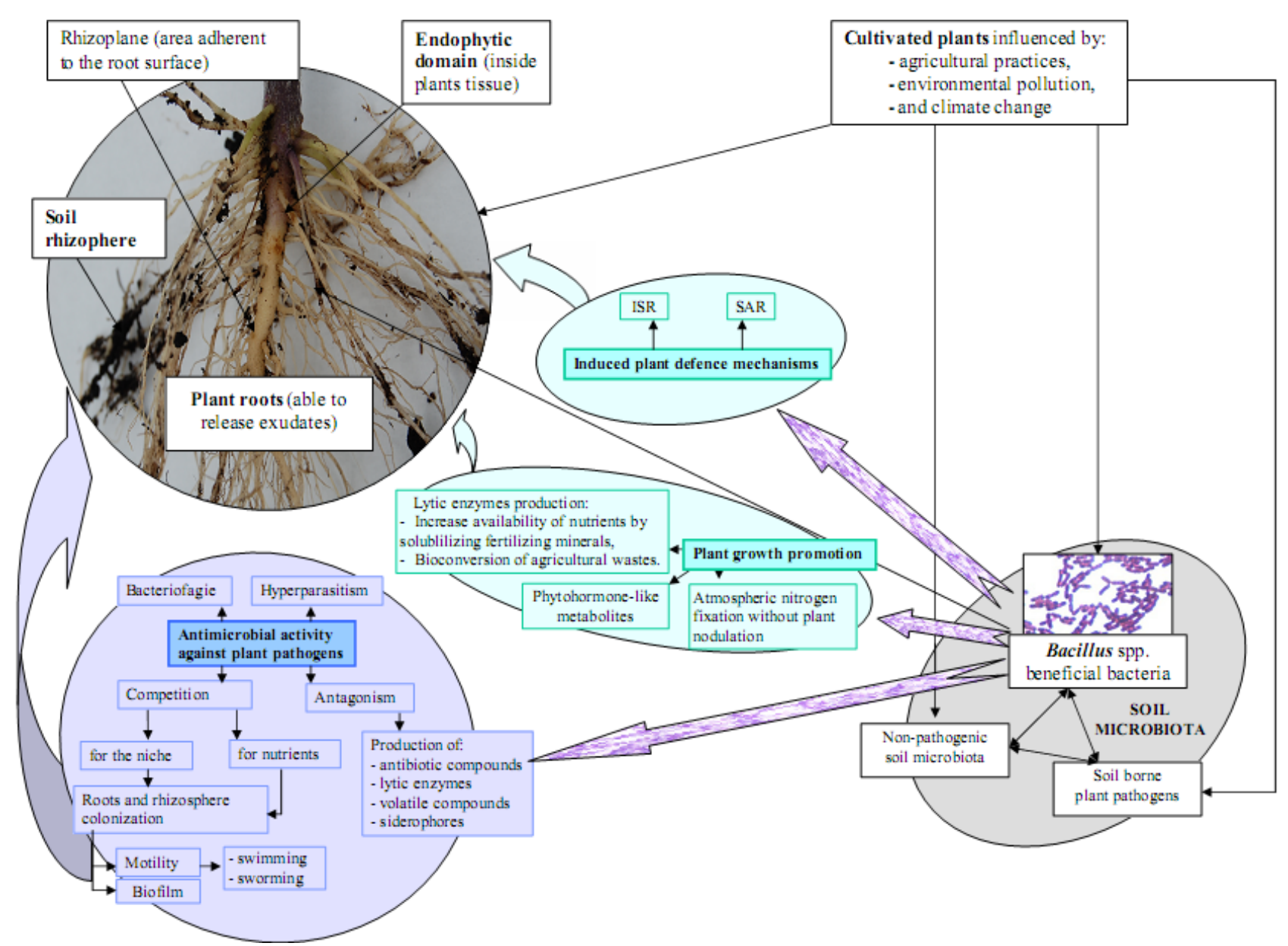

Fig. 1: The complex relations of plant-microbes interaction

Some endophytes showed specificity for a genotype or even cultivar [10]. In many cases, the biocontrol bacteria found in association with cultivated plants have an increased antagonistic potential against those phytopathogens specific for the same host. For example, some endophytic bacterial strains, found in wheat plants, expressed biocontrol activity against Fusarium graminearum responsible for the fusarium head blight and mycotoxins production in wheat [11]. Similar aspects reveal a better antagonistic efficacy of biocontrol bacteria against those pathogens infecting the same plant organs, were beneficial bacteria are habituated to survive. Considering these, [12] isolated from tomato leaves some biocontrol Bacillus strains, resistant to the tomato alkaloid alpha-tomatine, in order to suppress tomato leaf pathogens Fulvia fulva and Alternaria solani. Similar www.ijeab.com effects were also seen when [13], isolated from tomato rhizosphere several Bacillus species antagonistic to Fusarium oxisporum $\mathrm{f}$ sp. radicis-lycopersici involved in tomato foot and root rot.

\section{PLANT GROWTH PROMOTING ACTIVITY}

Plant growth promoting effects can be triggered by both endophytes and rhizosphere bacteria. However, due to the large mixture of colonizers and complex mechanisms of plant-microbe interactions it is not conclusively clear which bacteria is more involved in the plant benefit [10]. Since all PGPB species that colonize the host contribute to the wellness of the plant, are involved in a complex interrelation, it is quite difficult to differentiate each beneficial rate. Based on the scientific reports, it seems

Page | 138 
that Bacillus species are among the most abundant rhizosphere and endophytic bacteria found to colonize cultivated plants.

The hormone levels of auxins and citokinines induces the most visible effect on plant growth. Although most PGPR are phytohormones producers their effect is different from one host plant to another, thus having a significant aspect, considering the inoculating microbial bioproducts. The beneficial plant colonizers can also be involved in accelerating seedlings to emerge, enhancing growth, strengthening of protective barriers which also serve as supportive structures but, most importantly, release a complex mixture of metabolites and enzymes that regulate these plant behavior.

A few strains of Penibacillus sp. are mentioned to be involved in nitrogen fixation. These will be an important step, of long-standing interest, for developing biofertilizers that can help non-legume crops to "fix" nitrogen at the same time with maintaining growth yields [14].

Phosphate solubilization is another highly important tool in plant growth promotion. The only available phosphatic compound to higher plants is the soluble phosphate. Its low concentration in soluble forms makes it a limiting factor for plant growth, despite its naturally abundance in soil or as fertilizer apport [15]. The capability of PGPR to solubilize either organic or inorganic phosphorus becomes an important tool in plant development and growth promotion.

\section{ANTAGONISTIC EFFECT AGAINST PLANT PATHOGENS}

The common mechanisms expressed by biocontrol Bacillus in order to reduce pathogenic attack are competition for nutrients and niche, antagonistic activity, antibiotic synthesis, lytic enzyme production, siderophore formation, and other metabolites such as volatile compounds (2,3-butanediol and 3-hydroxy-2-butanone also known as acetoin), or quorum quenching mechanism [16].

It was observed that antibiotic synthesis is the most effective mechanism to suppress pathogen development when taking into account biological control. Regarding these aspects, scientific studies revealed that lipopeptide antibiotics, such as surfactin and iturins (including mycosubtilin) produced by Bacillus subtilis are able to reduce at least with $41 \%$ the leaves attack produced by Blumeria graminis f.sp. tritici responsible for powdery mildew and Mycosphaerella graminicola causing Septoria leaf blotch of wheat [17]. It was demonstrated that lipopeptide antibiotics interact with the fungal membrane and inhibit spores [18, 19]. Fungal spores inhibition of Alternaria solani, Fusarium sambucinum,
Rhizopus stolonifer and Verticillium dahliae was possible with lipopeptide antibiotics produced by B.subtilis [19, 20]. When biocontrol bacteria associate antibiotic synthesis with the production of another inhibitory mechanism the pathogenic spectrum is enlarged and plant defense is improved. For example, Bacillus amyloliquefaciens BW and OS17 strains, showed not only antibiotic production but other mechanism involved in biocontrol. As a result, they revealed, in vitro, a large antifungal spectrum against plant pathogenic fungi of Alternaria, Botrytis, Fusarium, Pythium, Rhizoctonia, Sclerotinia and Sclerotium species [21]. Bacterial strains isolated from cotton rhizosphere, inhibited Verticillium dahliae by producing antibiotics and volatile metabolites [22]. Iturin and surfactin synthesis associated with protease and lactonase production revealed the biocontrol ability of Bacillus subtilis B49b against Fusarium oxysporum f.sp. radicis lycopersici [23].

\section{INDUCTION OF PLANT DEFENSIVE MECHANIAMS}

The mechanism enhancing a defensive reaction in plants is effective against a broad range of pathogens and parasites, including fungi, bacteria, viruses, nematodes, insects and even parasitic plants [24]. In this way, diseases incidence or severity can be reduced by elicitation of ISR (induced systemic resistance).

Several studies revealed the some biocontrol strains of Bacillus spp. are able to induce plant resistance to pathogen attack. In some cases this mechanism was associated to lipopeptide antibiotics released by the Bacillus strains. The lipopeptide compounds, surfactins, iturins and fengycins, produced by Bacillus strains shown to be elicitors and induce systemic resistance in plants [25, 26]. Strains of Bacillus amyloliquefaciens producing iturin A, fengycin, mixirin, pumilacidin and surfactin were described to control the anthracnose (produced by Colletothichum gloeosporoides) in strawberries [27] and induce rezistance to rhizomania (Polymixa betae) in Beta vulgaris [28].

Not only biocontrol strains are able to induce plant defence mechanisms against pathogenic attacks, but also PGPR (plant growth promoting rhizobacteria. In this regard, it was shown that strains of Bacillus subtilis and B. pumilus can enhance seed germination of Vigna unguiculata, offering protection against blackeye cowpea mosaic strain of Bean Common Mosaic Virus to the cowpea plants [29]. Similar results were described in tobacco plants treated with PGPR. In these cases, the Bacillus spp. increased plant height and fresh weight, while lowering the disease severity caused by Tobacco Mosaic Virus infections [30]. 
Defensive mechanisms can also be induced for abiotic stress tolerance. In this regard, some authors presented a B. amyloliquefaciens strain able to modulate gene expression in rice plants during salt stress [31]. For a similar purpose, Forchetti et al. [32] mentioned two Bacillus pumilus strain producing salycilic acid that simultaneously helped plants during water stress, stimulated sunflower growth, and inhibited the growth of Alternaria sp., Sclerotinia sp., and Verticillum sp. pathogenic fungi.

\section{MICROBIAL FORMULATION AS BIOPRODUCTS}

A diversity of formulation types have been created and tested in order to simplify the application of microbial selected strains. Through the formulations process, scientists were able to obtain microbial based bioproducts, biofertilizers, or even biopesticides. Such bio-based products are presented either as microbial strains multiplied on organic or synthetic media, or as microbial biomass harvested from a bioreactor and formulated as concentrated suspensions, wettable powder, granules, emulsions or effervescent tablets. In some formulations bacterial strains was included in organic fertilizer to fight against Fusarium [33]. In other formulations, Bacillus megatherium was included in alginate microcapsules [34], in pellets [35], or in formulations with effervescent systems, in order to release rapidly the bacteria [36]. The microbial preparation can be sometime used together with organic amendments to improve soil in semiarid areas [37].

\section{DISCUSSIONS}

Environmental microbiology promoted the soil microorganisms that are able to decompose the organic matter and improve soil fertility. Similar studies described microbial strains with complex role as plants growth promoters. Those two types of beneficial microorganisms are much easier implemented in contrast with the biocontrol strains. The legislation is less permissive with plant protection microorganisms, compared to the microbial biofertilizers. Since biological control means are included in the plant protection products, for their authorization being required, not only efficacy studies but also toxicological, residues, ecotoxicological and environmental studies, according to the same legislation as for chemical pesticides. Despite the obvious benefits for environmental protection, this aspect is a drawback for biopesticide diversification and expansion on the market. Since the governmental context is very restrictive in authorizing biological pesticides, finding competitive and highly efficient biocontrol strains is still a challenge.

\section{CONCLUSIONS}

The relations between plants and beneficial bacteria are mutual or symbiotic. Either as endophytes or rhizospheric microorganisms, the beneficial bacteria use their host plants as habitat, in which they are releasing phytostimulatory compounds, and at the same time, with a protective role against deleterious pests or diseases. In the present study we revealed only few examples of complex relations between cultivated plants and a small part of the culturable beneficial microbiota. Such a mechanism is which the beneficial Bacillus strains are releasing antibiotics and other metabolites and lytic enzymes with inhibitory effect against plant pathogens, are involved not only as biological control but also in order to protect their hosting environment. A similar aspect is involved when referring to the inducing plant resistance to deleterious biotic and abiotic conditions or when bacteria enhance plant growth. For the progress of modern agriculture, en improvement of soil microbiota with plant beneficial bacteria is the most productive and non-invasive way to increase yield productivity and plant health. Selected Bacillus strains, as they are spore forming bacteria, present clear benefits as bio-based inoculants as they are easy to formulate and preserve, thus having market potential.

\section{ACKNOWLEDGEMENTS}

This article is published in the frame of PN 16290201 project: "Sustainable management of phytosanitary risks through the application of complex biological means along with chemicals pesticides of low toxicity".

\section{REFERENCES}

[1] T. de Los Milagros Orberá Ratón, R. Yano, O. Rodríguez Gámez, E.I. Floh, M. de Jesús Serrat Díaz, and H.R. Barbosa. "Isolation and characterisation of aerobic endospore forming Bacilli from sugarcane rhizosphere for the selection of strains with agriculture potentialities." World J Microbiol Biotechnol., 2012, vol. 28 (4), pp: 15931603. doi: 10.1007/s11274-011-0965-2.

[2] P.N. Bhattacharyya, and D.K. Jha. "Plant growthpromoting rhizobacteria (PGPR): emergence in agriculture". World J Microbiol Biotechnol., 2012, vol. 28(4), pp:1327-1350. doi: 10.1007/s11274-0110979-9.

[3] M. Saleem, M. Arshad, S. Hussain, and A.S. Bhatti. "Perspective of plant growth promoting rhizobacteria (PGPR) containing ACC deaminase in stress agriculture". J Ind Microbiol Biotechnol, 2007, vol. 34(10), pp: 635-648. 
[4] S. Kadyan, M. Panghal, S. Kumar, K. Singh, and J.P. Yadav. "Assessment of functional and genetic diversity of aerobic endospore forming Bacilli from rhizospheric soil of Phyllanthus amarus L.”. World J Microbiol Biotechnol., 2013, vol. 29(9), pp: 15971610. doi: 10.1007/s11274-013-1323-3.

[5] F. Constantinescu, O.A. Sicuia, R. Zamfiropol, Dinu S., and F. Oancea. "Beneficial characteristics of some bacterial strains isolated from rhizosphere". Romanian Journal of Plant Protection, 2010, vol. 3, pp: 6-11.

[6] D. Bulgarelli, K. Schlaeppi, S. Spaepen, E. Ver Loren van Themaat, and P. Schulze-Lefert. "Structure and functions of the bacterial microbiota of plants". Annu Rev Plant Biol., 2013, vol. 64, pp: 807-838. doi: 10.1146/annurev-arplant-050312120106.

[7] R.T. Vendan, Y.J. Yu, S.H. Lee, and Y.H. Rhee. "Diversity of endophytic bacteria in ginseng and their potential for plant growth promotion". J Microbiol., 2010, vol. 48(5), pp: 559-565. doi: 10.1007/s12275-010-0082-1.

[8] S.S. Dudeja, and R. Giri. "Beneficial properties, colonization, establishment and molecular diversity of endophytic bacteria in legumes and non legumes". African Journal of Microbiology Research, 2014, vol. 8(15), pp: 1562-1572. doi: 10.5897/AJMR2013.6541

[9] G.V. de Melo Pereira, K.T. Magalhães, E.R. Lorenzetii, T.P. Souza, and R.F. Schwan. "A multiphasic approach for the identification of endophytic bacterial in strawberry fruit and their potential for plant growth promotion". Microb Ecol., 2012, vol. 63(2), pp: 405-417. doi: 10.1007/s00248011-9919-3.

[10] S.S. Dudeja, R. Giri, R. Saini, P. Suneja-Madan, and E. Kothe. "Interaction of endophytic microbes with legumes”. J Basic Microbiol., 2012, vol. 52(3), pp: 248-260. doi: 10.1002/jobm.201100063.

[11]D. Pan, A. Mionetto, S. Tiscornia, and L. Bettucci,. "Endophytic bacteria from wheat grain as biocontrol agents of Fusarium graminearum and deoxynivalenol production in wheat". Mycotoxin Res., 2015, vol. 31(3), pp: 137-146. doi: 10.1007/s12550-015-0224-8.

[12] J. Enya, H. Shinohara, S. Yoshida, T. Tsukiboshi, H. Negishi, K. Suyama, and S. Tsushima. "Culturable leaf-associated bacteria on tomato plants and their potential as biological control agents". Microb Ecol., 2007, vol. 53(4), pp: 524-536. doi: 0.1007/s00248006-9085-1
[13] J.D. Cordero-Ramírez, R. López-Rivera, A.M. Figueroa-Lopez, M.E. Mancera-López, J.C. Martínez-Álvarez, M.Á. Apodaca-Sánchez, and I.E. Maldonado-Mendoza. "Native soil bacteria isolates in Mexico exhibit a promising antagonistic effect against Fusarium oxysporum f. sp. radicislycopersici". J Basic Microbiol., 2013, vol. 3(10), pp: 838-847. doi: 10.1002/jobm.201200128.

[14]L. Wang, L. Zhang, Z. Liu, D. Zhao, X. Liu, B. Zhang, J. Xie, Y. Hong, P. Li, S. Chen, R. Dixon, and J. Li. "A Minimal Nitrogen Fixation Gene Cluster from Paenibacillus sp. WLY78 Enables Expression of Active Nitrogenase in Escherichia coli". PLoS Genetic, 2013, vol. 9(10): e1003865. doi: 10.1371/journal.pgen.1003865

[15]N. Uma Maheswar, and G. Sathiyavani. "Solubilization of phosphate by Bacillus spp, from groundnut rhizosphere (Arachis hypogaea L)". Journal of Chemical and Pharmaceutical Research, 2012, vol. 4(8), pp: 4007-4011.

[16] O.A. Sicuia, F. Constantinscu, and C.P. Cornea. "Biodiversity of Bacillus subtilis group and beneficial traits of Bacillus species useful in plant protection". Romanian Biotechnological Letters, 2015, vol. 20 (5), pp: 10737-10750.

[17] N.G. Khong, B. Randoux, J. Deravel, B. Tisserant, Ch. Tayeh, F. Coutte, N. Bourdon, P. Jacques, and P. Reignault. "Induction of resistance in wheat by bacterial cyclic lipopeptides". Commun Agric Appl Biol Sci., 2013, vol. 78(3), pp: 479-487.

[18] J. Falardeau, C. Wise, L. Novitsky, and T.J. Avis. "Ecological and mechanistic insights into the direct and indirect antimicrobial properties of Bacillus subtilis lipopeptides on plant pathogens". J Chem Ecol., 2013, vol. 39(7), pp: 869-78. doi: 10.1007/s10886-013-0319-7.

[19] J. Liu, I. Hagberg, L. Novitsky, H. Hadj-Moussa, and T.J. Avis. "Interaction of antimicrobial cyclic lipopeptides from Bacillus subtilis influences their effect on spore germination and membrane permeability in fungal plant pathogens". Fungal Biol., 2014, vol. 118(11), pp: 855-861. doi: 10.1016/j.funbio.2014.07.004.

[20]A. El Hadrami, L.R. Adam, and F. Daayf. "Biocontrol treatments confer protection against Verticillium dahliae infection of potato by inducing antimicrobial metabolites". Mol Plant Microbe Interact., 2011, vol. 24(3), pp: 328-335. doi: 10.1094/MPMI-04-10-0098.

[21]O.A. Sicuia. „Cercetări la nivel molecular şi celular privind mecanisme de interacţiune între microorganisme din rizosferă şi plante de interes 
economic". PhD thesis., Universitatea Bucureşti, Facultatea de Biologie, 2012, 242p.

[22] A.S. Tehrani, F.A. Disfani, G.A. Hedjaroud, and M. Mohammadi. „Antagonistic effects of several bacteria on Verticillium dahliae the causal agent of cotton wilt“. Meded Rijksuniv Gent Fak Landbouwkd Toegep Biol Wet., 2001, vol. 66(2a), pp: 95-101.

[23]F. Constantinescu, G.P. Voshol, and G.V. Bloemberg. "Mechanisms involved in biocontrol activity of $B$. subtilis B49b against Fusarium oxysporum f.sp. radicis lycopersici, Molecular Tools for Understanding and Improving Biocontrol". IOBC/wprs Bulletin, 2009, vol. 43, pp: 113-116.

[24]L.C. Van Loon, P.A.H.M. Bakker, and M.J. Pieterse. "Systemic induced resistance by rhizosphere bacteria". Annu. Rev. Phytopathol., 1998, vol. 36, pp: 453-483. doi: 10.1146/annurev.phyto.36.1.453

[25] M. Ongena, E. Jourdan, A. Adam, M. Paquot, A. Brans, B. Joris, and J.L. Arpigny." Surfactin and fengycin lipopeptides of Bacillus subtilis as elicitors of induced systemic resistance in plants". Environ Microbiol., 2007, vol. 9(4), pp: 1084-1090. 10.1111/j.1462-2920.2006.01202.x

[26] M. Ongena, and P. Jacques. "Bacillus lipopeptides: versatile weapons for plant disease biocontrol". Trends Microbiol., 2008, vol. 16(3), pp: 115-125. doi: 10.1016/j.tim.2007.12.009.

[27] S. Yamamoto, S. Shiraishi, and S. Suzuki. "Are cyclic lipopeptides produced by Bacillus amyloliquefaciens S13-3 responsible for the plant defence response in strawberry against Colletotrichum gloeosporioides?". Lett Appl Microbiol., 2015, vol. 60 (4), pp: 379-86. doi: 10.1111/lam.12382.

[28] N. Desoignies, F. Schramme, M. Ongena, and A. Legrève. "Systemic resistance induced by Bacillus lipopeptides in Beta vulgaris reduces infection by the rhizomania disease vector Polymyxa betae". Mol Plant Pathol., 2013, vol. 14(4), pp: 416-421. doi: 10.1111/mpp. 12008 .

[29]A.C. Udaya Shankar, S. Chandra Nayaka, S. Niranjan-Raj, H. Bhuvanendra Kumar, M.S. Reddy, S.R. Niranjana, and H.S. Prakash. "Rhizobacteriamediated resistance against the blackeye cowpea mosaic strain of bean common mosaic virus in cowpea (Vigna unguiculata)". Pest Manag Sci., 2009, vol. 65(10), pp: 1059-1064. doi: 10.1002/ps.1791.

[30] S. Wang, H. Wu, J. Qiao, L. Ma, J. Liu, Y. Xia., and X. Gao. "Molecular Mechanism of Plant Growth
Promotion and Induced Systemic Resistance to Tobacco Mosaic Virus by Bacillus spp.". J. Microbiol. Biotechnol., 2009, vol. 19 (10), pp: 1250-1258. doi: 10.4014/jmb.0901.008

[31]C.S. Nautiyal, S. Srivastava, P.S. Chauhan, K. Seem, A. Mishra, and S.K. Sopory. "Plant growthpromoting bacteria Bacillus amyloliquefaciens NBRISN13 modulates gene expression profile of leaf and rhizosphere community in rice during salt stress". Plant Physiol Biochem., 2013, vol. 66, pp: 19. doi: 10.1016/j.plaphy.2013.01.020.

[32]G. Forchetti, O. Masciarelli, M.J. Izaguirre, S. Alemano, D. Alvarez, and G. Abdala. "Endophytic bacteria improve seedling growth of sunflower under water stress, produce salicylic acid, and inhibit growth of pathogenic fungi". Curr Microbiol., 2010, vol. 61(6), pp: 485-493. doi: 10.1007/s00284-010-9642-1.

[33] J. Yuan, Y. Ruan, B. Wang, J. Zhang, R. Waseem, Q. Huang, and Q. Shen. „Plant growth-promoting rhizobacteria strain Bacillus amyloliquefaciens NJN6-enriched bio-organic fertilizer suppressed Fusarium wilt and promoted the growth of banana plants“. J Agric Food Chem., 2013, vol. 61(16), pp: 3774-3780. doi: 10.1021/jf400038z.

[34]R. Wiwattanapatapee, A. Chumthong, A. Pengnoo, M. Kanjanamaneesathian. "Preparation and evaluation of Bacillus megaterium-alginate microcapsules for control of rice sheath blight disease". World J Microbiol Biotechnol., 2013, vol. 29(8), pp: 1487-1497. doi: 10.1007/s11274-0131314-4.

[35]R. Wiwattanapatapee, A. Pengnoo, M. Kanjanamaneesathian, W. Matchavanich, L. Nilratana, and A. Jantharangsri. "Floating pellets containing bacterial antagonist for control sheath blight of rice: formulations, viability and bacterial release studies". J Control Release., 2004, vol. 95 (3), pp: 455-462.

[36]R. Wiwattanapatapee, A. Chumthong, A. Pengnoo, and M. Kanjanamaneesathian. "Effervescent fastdisintegrating bacterial formulation for biological control of rice sheath blight". Journal of Controlled Release, 2007, vol. 119, pp: 229-235.

[37]C. Mengual, M. Schoebitz, R. Azcón, and A. Roldán. "Microbial inoculants and organic amendment improves plant establishment and soil rehabilitation under semiarid conditions". J Environ Manage., 2014, vol. 134, pp: 1-7. doi: 10.1016/j.jenvman.2014.01.008. 